\title{
Serum Leptin Correlated with Anthropometric Indices in obese Subjects
}

\section{Ebesunun $\mathrm{MO}^{1 *}$ and Okeke $\mathrm{DC}^{2}$}

${ }^{1}$ Chemical Pathology Faculty of Basic Medical Sciences, Obafemi Awolowo College of Health Sciences, Olabisi Onabanjo University Sagamu campus, Nigeria ${ }^{2}$ National Orthopedic Hospital, Lagos, Nigeria

\begin{abstract}
Background: Obesity has become a worldwide concern. Elevated serum leptin has been implicated in obesity in some populations. There is paucity of information on leptin and obesity in Nigeria. This study was designed to evaluate serum leptin, lipids and lipoproteins levels in relationship to anthropometric indices in obese Nigerians.
\end{abstract}

Methods: Two hundred and seventeen subjects consisting of 154 obese age $44.55 \pm 8.81$ years and 63 ideal body weight and age matched controls were recruited. The obese group consisted of 120 females and 34 males while the controls were 32 females and 31 males. Anthropometric indices, serum leptin, lipids and lipoproteins were determined using standard procedures.

Results: Results showed significant increases in serum leptin $(p<0.001)$, plasma triglyceride $(T G)(p<0.01)$ and LDLC: HDLC ratio $(p<0.05)$ when compared with the control values. A significant decreased was obtained in plasma HDLC $(p<0.01)$ in the obese siubjects. The obese females had a higher serum leptin than obese males. There were significant increases in the body weight, waist circumference (WC) and hip circumference (HC), BMI and \%body fat $(\% B F)(p<0.001)$ as well as waist: hip ratio $(W H R)(p<0.05)$ when compared with the control values. Leptin was significantly correlated with WC, HC, BMI, WHR and \%BF.

Conclusion: Elevated serum leptin in obese Nigerians with increased plasma TG and decreased HDLC was significantly correlated with anthropometric indices, indications for metabolic syndrome and other chronic diseases.

Keywords: BMI; Body fat; Leptin; Obese; Lipids; Lipoproteins; WHR

\section{Introduction}

Obesity has become a worldwide concern because of its association with higher rates of chronic medical conditions such as metabolic syndrome, CVD and type 2 diabetes and worse physical health-related quality of life [1]. The rising epidemic reflects the profound changes in society and in behavioural patterns of communities over recent decades [1]. At an individual level, obesity results from energy imbalance-too many calories in, too few calories burned. But the food and physical activity choices that individuals make are shaped by the world in which they live. Due to globalization, the world is getting wealthier, and wealth and weight are linked $[2,3]$. Poor city-dwellers may now have enough money to pick up "modern habits associated with obesity" [4]-watching television, buying processed foods at supermarkets and eating more food away from home.

As countries start to move up the income scale, obesity rates climb too. World Health Organization gave an estimated 300 million people as clinically obese worldwide [5] and this has become an increasing challenge throughout the world including the developing country. In Nigeria modern habits associated with obesity are on the rise, the few available studies on obesity have put the prevalence rate at $4-5 \%[6,7]$.

Report from the Framingham study showed an increased incidence of cardiovascular events with increasing weight in both men and women [8]. Body weight and mortality were directly related in the Harvard Alumni Health Study [9] and weight gain was reported as a significant risk factor for the development of diabetes mellitus in women.

Leptin, a product of $\mathrm{Ob}$ gene, made up of highly conserved 167-amino-acid sequences and secreted by adipose tissue, is thought to act as lipostat, and is considered to play an important role in appetite control, fat metabolism, and regulation of body weight. As the amount of fat stored in adipocytes rises, leptin is released into the blood and signals to the brain that the body has had enough to eat. The amount of stored energy (fat mass) results from a complex interplay of biological factors responding to variations in energy intake and expenditure that depend on behaviour and environmental conditions. Leptin plays a key role in this homeostasis. It plays a crucial role in the regulation of body weight by inhibiting food intake and stimulating energy expenditure [10]. Studies from different populations have demonstrated changes in serum leptin concentrations in human obesity in proportion to the degree of adiposity $[1,12]$. Report from a study on mice showed that serum triglycerides play a key role in the transport of leptin [13]. Because serum triglycerides are elevated in obses subjects, postulates have been formed that link triglycerides with inhibited leptin transport [13].

An earlier study [14] has indicated that obesity was mainly associated with the industrialized nations. Little or no available study in Nigeria has indicated any relationship between serum leptin and obese individuals. Report has also shown that serum leptin varies between populations [15]. The exact mechanisms that underlie population variation independent of adiposity remain unclear, however genetic differences between populations, chronic environmental influences such as maternal/fetal or childhood nutritional status, and acute lifestyle differences such as diet and physical activity may be contributory [15]. The relationship between obesity and income in men varies by race and ethnicity, and the prevalence is thought to decrease as income reduces [16].

This study was designed to evaluate serum leptin, lipids, and lipoproteins in relation to body compositions in obese subjects at different socioeconomic status.

*Corresponding author: Ebesunun $\mathrm{MO}$, Chemical Pathology \& Immunology Faculty of Basic Medical Sciences, Obafemi Awolowo College of Health Sciences, Olabisi Onabanjo University, Sagamu campus, Nigeria, Tel: 234805 5307626; E-mail: onomhaguan25@gmail.com

Received June 21, 2014; Accepted August 27, 2014; Published September 01, 2014

Citation: Ebesunun MO, Okeke DC (2014) Serum Leptin Correlated with Anthropometric Indices in obese Subjects. J Metabolic Synd 3: 157. doi:10.4172/2167-0943.1000157

Copyright: @ 2014 Ebesunun MO, et al. This is an open-access article distributed under the terms of the Creative Commons Attribution License, which permits unrestricted use, distribution, and reproduction in any medium, provided the original author and source are credited. 


\section{Materials and Methods}

Two hundred and seventeen (217) free living adults 18-60 years were selected for this study. It comprised of 154 obese subjects $(120$ females and 34 males). Seventy nine females and thirty one males (50.7\%) were in obese class I, thirty females and two males $(44.2 \%)$ were in obese class II while obese class III has ten females and one male (5.1\%). Sixty three (63) ideal body weight subjects with BMI 17.5 - $25 \mathrm{~kg} / \mathrm{m}^{2}$ were included as controls. All participants were apparently healthy urban city dwellers.

Data from the completed questionnaire administered by one of us, indicating the educational level, occupation, income (earning) and living conditions such as ownership of material goods were used as a measure of socio-economic status to classify the subjects into low income (petty traders, farmers, artisans, cleaners and junior staff in public offices with primary/secondary education), middle income (workers in the senior level cadre with university or polytechnics/higher education) and high income (executive business class, captains of industries and directors of institutions) groups respectively as adopted in earlier study [17] in this community. A written/oral informed consent was obtained from each participant.

Pregnant women, subjects on lithium and corticosteroid drugs and lipid lowering drugs were excluded from the study. Ethical approval was obtained from theInstitutional Ethical Committee.

\section{Anthropometric measurement}

The weight in kilograms, percentage body fat (\%BF) and BMI in kg/ $\mathrm{m}^{2}$ of all subjects were determined using the body fat monitor machine (bioelectric impedance) (BF-400) manufactured by Omron Healthcare, United Kingdom.

Height was taken with the subjects in a standing position, without footwear with a graduated measuring rod. This height was measured to an accuracy of 0.1 centimetres. The height in centimetres, age in years and sex of each subject were fed into the BF-400 scale. The subjects were then asked to stand on the scale after calibration. The body weight, $\mathrm{BMI}$ and percentage body fat were displayed on the scale and these were recorded. All readings were taken in the morning after wake (between 8 -10am) before breakfast as recommended by the manufacturer (Omron Healthcare, United Kingdom).

Waist circumference was taken with non-stretchable tape rule at the minimum circumference between the coastal margins and the iliac crest, measured in the horizontal plane with subject standing. Hip circumference was taken with non-stretchable tape rule at the maximum circumference in the horizontal plane measured over the buttocks.

\section{Blood sample collection}

Blood samples were collected after overnight fast (8-12hours). The blood was dispensed into fluoride oxalate for glucose estimation, Potassium-Ethylene-Diamine Tetracetic Acid (KEDTA) for lipids and lipoproteins and plain bottles for leptin analysis. The blood collected into plain bottles was allowed to clot and retract. All samples were centrifuged at 2,500 rpm for 5 minutes and the plasma or serum was collected into screw capped bottles and kept frozen at $-20^{\circ} \mathrm{C}$ until assayed.

\section{Methods}

\section{Leptin analysis}

The Diagnostic Automation Incorporation (DAI), leptin enzyme immunoassay kit was used.
The DAI leptin kit is a solid phase enzyme - linked immunosorbent assay (ELISA) based on the sandwich principle. The micro-titer wells were coated with a monoclonal antibody directed towards a unique antigenic site on a leptin molecule. An aliquot of subject's sample containing endogenous leptin was incubated in the coated well with a specific rabbit anti-leptin antibody. A sandwich complex was formed. After incubation the unbound material was washed off and an antirabbit peroxidase conjugate was added for detection of the bound leptin. The intensity of colour developed was proportional to the concentration of leptin in the sample.

Reagents for determination of plasma total cholesterol (TC) were obtained from Quimica Clinica Aplicada S.A. (QCA) in Spain. It was based on the method of Allain et al. [18].

Plasma triglyceride was estimated using glycerol-phosphate oxidase method McGowan et al. [19] obtained from QCA in Spain.

Dextran-sulphate-Mg II precipitant reagent obtained from QCA in Spain was used to precipitate low density lipoprotein cholesterol (LDLC) and very low density lipoprotein cholesterol (VLDLC) from the plasma by the action of a polysaccharide in the presence of divalent cations (magnesium ions). HDLC present in the supernatant was determined using the cholesterol oxidase - peroxidase method (18). LDLC was calculated using Friedwald et al. formula [20].

Plasma glucose was determined using glucose oxidase (GOD), Peroxidase (POD reagent [21] manufactured by Randox Laboratories in the United Kingdom. Accuracy and precision of biochemical tests were monitored by including commercial quality control samples within each batch of test assay.

\section{Statistical analysis}

All results were subjected to statistical analysis using the SPSS software package (2001) version. The difference between means was assessed using Sstudent's t-test. Analysis of variance (ANOVA) was used to determine differences within groups. Pearson correlation coefficient was used to determine association between parameters. The results were expressed as mean \pm SEM and the difference was regarded as significant at $\mathrm{p}<0.05$.

\section{Results}

Table 1 shows the biophysical parameters of all subjects. There were significant increases in body weight, waist circumference, hip circumference, BMI, \%BF $(\mathrm{p}<0.001)$ as well as WHR $(\mathrm{p}<0.05)$ in obese subjects when compared with the corresponding control values. The obese subjects were shorter than the control group $(\mathrm{p}<0.05)$.

Table 2 shows the biochemical characteristics of obese and control group. Significant increases were observed in serum leptin $(\mathrm{p}<0.001)$,

\begin{tabular}{|l|c|c|c|c|}
\hline Variables & Obese $(\mathbf{n}=\mathbf{1 5 4})$ & Non obese $(\mathbf{n}=\mathbf{6 3})$ & t-value & $\mathbf{p}$-value \\
\hline Weight $(\mathrm{kg})$ & $91.66 \pm 11.10$ & $66.31 \pm 1.10$ & 13.540 & $\mathrm{p}<0.001$ \\
\hline Height $(\mathrm{cm})$ & $163.75 \pm 0.80$ & $166.65 \pm 1.57$ & -2.110 & $\mathrm{p}<0.05$ \\
\hline $\mathrm{WC}(\mathrm{cm})$ & $98.65 \pm .70$ & $79.02 \pm 1.15$ & 14.850 & $\mathrm{p}<0.001$ \\
\hline $\mathrm{HC}(\mathrm{cm})$ & $114.51 \pm .80$ & $94.43 \pm 1.14$ & 14.090 & $\mathrm{p}<0.001$ \\
\hline WHR & $0.86 \pm 0.008$ & $0.84 \pm 0.007$ & 2.497 & $\mathrm{p}<0.05$ \\
\hline BMl $\left(\mathrm{kg} / \mathrm{m}^{2}\right)$ & $34.12 \pm 3.54$ & $24.23 \pm 7.33$ & 13.853 & $\mathrm{p}<0.001$ \\
\hline$\%$ Body Fat & $42.47 \pm .63$ & $28.63 \pm 1.03$ & 11.625 & $\mathrm{p}<0.001$ \\
\hline
\end{tabular}

SEM: Standard Error; BMI: Body Mass Index; WHR: Waist to Hip Ratio; WC: Wais Circumference

HC: Hip Circumference

Table 1: The Biophysical Parameters in all subjects (Means \pm SEM). 
Citation: Ebesunun MO, Okeke DC (2014) Serum Leptin Correlated with Anthropometric Indices in obese Subjects. J Metabolic Synd 3: 157. doi:10.4172/2167-0943.1000157

Page 3 of 5

plasma TG and LDLC: HDLC $(\mathrm{p}<0.01)$ in the obese subjects when compared with the corresponding control values. A significant decrease was obtained in plasma HDLC level $(\mathrm{p}<0.01)$ when compared with the control value. No significant changes were obtained in the other parameters.

Table 3 shows serum leptin levels in the different obese groups. The mean serum leptin levels were higher in all female subjects with obese class III showing the highest mean values. Within group analysis showed a significant increase in serum leptin levels in the obese female subjects $(\mathrm{p}<0.001)$. Post hoc analysis showed increases in serum leptin in all obese classes.

Table 4 shows the biochemical parameters in the obese females and males. The mean plasma triglyceride $(p<0.01)$ was significantly increased in obese male when compared with the corresponding values in the obese females while the serum leptin was significantly higher in the obese females when compared with the corresponding obese male value $(\mathrm{p}<0.001)$.

No significant differences were obtained in the other parameters.

Table 5 shows Pearson correlation coefficient of biophysical parameters and serum leptin in the obese subjects. Serum leptin was significant correlated with body weight $(\mathrm{r}=0.164, \mathrm{p}<0.05)$, height

\begin{tabular}{|l|c|c|c|c|}
\hline Variables & Obese $(\mathbf{n}=\mathbf{1 5 4})$ & Controls $(\mathbf{n}=\mathbf{6 3})$ & $\mathbf{t}$-value & $\mathbf{p}$ - value \\
\hline FPG $(\mathrm{mg} / \mathrm{dl})$ & $87.71 \pm 2.24$ & $82.98 \pm 2.37$ & 1.54 & $\mathrm{NS}$ \\
\hline TC $(\mathrm{mg} / \mathrm{dl})$ & $215.68 \pm 4.35$ & $208 \pm 6.27$ & 0.795 & $\mathrm{NS}$ \\
\hline TG $(\mathrm{mg} / \mathrm{dl})$ & $102.51 \pm 3.35$ & $87.84 \pm 4.35$ & 5.12 & $\mathrm{p}<0.01$ \\
\hline HDLC $(\mathrm{mg} / \mathrm{dl})$ & $41.47 \pm 0.99$ & $47.53 \pm 1.11$ & -2.874 & $\mathrm{p}<0.01$ \\
\hline LDLC $(\mathrm{mg} / \mathrm{dl})$ & $152.68 \pm 4.31$ & $144.81 \pm 5.80$ & 1.023 & $\mathrm{NS}$ \\
\hline Leptin $(\mathrm{ng} / \mathrm{ml})$ & $47.07 \pm 3.18$ & $19.62 \pm 2.94$ & 8.916 & $\mathrm{p}<0.001$ \\
\hline HDLC:TC & $0.205 \pm 0.01$ & $0.240 \pm 0.01$ & -1.841 & $\mathrm{NS}$ \\
\hline LDLC:HDLC & $4.11 \pm 0.17$ & $3.18 \pm 0.16$ & 2.324 & $\mathrm{p}<0.01$ \\
\hline
\end{tabular}

SEM: Standard Error of Mean; NS: Not Significant; FPG: Fasting Plasma Glucose; HDLC: High Density Lipoprotein Cholesterol; LDLC: Low Density Lipoprotein Cholesterol; TC: Total Cholesterol; TG: Triglyceride

Table 2: Biochemical Characteristics of the Obese and Controls (Mean \pm SEM).

\begin{tabular}{|l|c|c|}
\hline & Females leptin $(\mathbf{n g} / \mathbf{m l})$ & Males leptin $(\mathbf{n g} / \mathbf{m l})$ \\
\hline Controls & $31.12 \pm 4.75(n=32)$ & $7.74 \pm 1.73(n=31)$ \\
\hline Obese I & $71.36 \pm 3.91(n=79)$ & $24.08 \pm 3.89(n=31)$ \\
\hline Obese II & $88.89 \pm 6.11(n=31)$ & $43.60 \pm 27.60(n=2)$ \\
\hline Obese III & $103.98 \pm 5.37(n=10)$ & $45.46(n=1)$ \\
\hline
\end{tabular}

SEM: Standard Error of Mean; BMI: Body Mass Index; F-value: 39.186; $p<0.001$

Table 3: Serum Leptin Levels in the different Obese and Control groups based on gender (Mean $\pm \mathrm{SE}$ ).

\begin{tabular}{|l|c|c|c|c|}
\hline Variables & $\begin{array}{c}\text { Obese Females } \\
(\mathbf{n}=\mathbf{1 2 0})\end{array}$ & $\begin{array}{c}\text { Obese Males } \\
(\mathbf{n}=\mathbf{3 4})\end{array}$ & t. value & p- value \\
\hline FPG $(\mathrm{mg} / \mathrm{dl})$ & $88.26 \pm 2.72$ & $85.79 \pm 3.32$ & -0.344 & $\mathrm{NS}$ \\
\hline TC $(\mathrm{mg} / \mathrm{dl})$ & $217.07 \pm 4.88$ & $210.76 \pm 9.67$ & -0.754 & $\mathrm{NS}$ \\
\hline TG $(\mathrm{mg} / \mathrm{dl})$ & $96.93 \pm 3.44$ & $122.18 \pm 8.36$ & 2.830 & $\mathrm{p}<0.01$ \\
\hline HDLC $(\mathrm{mg} / \mathrm{dl})$ & $41.86 \pm 1.16$ & $40.09 \pm 1.85$ & -0.738 & $\mathrm{NS}$ \\
\hline LDLC $(\mathrm{mg} / \mathrm{dl})$ & $155.23 \pm 4.86$ & $143.68 \pm 9.31$ & -1.040 & $\mathrm{NS}$ \\
\hline HDLC/TC & $0.205 \pm .01$ & $0.206 \pm .01$ & 0.105 & $\mathrm{NS}$ \\
\hline LDLC/HDLC & $4.15 \pm .19$ & $3.98 \pm .36$ & -0.420 & $\mathrm{NS}$ \\
\hline Leptin $(\mathrm{ng} / \mathrm{ml})$ & $78.61 \pm 3.191$ & $26.15 \pm 4.26$ & 7.79 & $\mathrm{p}<0.001$ \\
\hline
\end{tabular}

NS: Not Significant; SEM: Standard Error of Mean; FPG: Fasting Plasma Glucose; HDLC: High Density Lipoprotein Cholesterol; LDLC: Low Density Lipoprotein Cholesterol; TC: Total Cholesterol; TG: Triglyceride

Table 4: Biochemical Parameters in Obese Females and Males (Mean \pm S. E).

\begin{tabular}{|l|c|c|}
\hline Variables & r value & p-value \\
\hline Weight vs BMI & $0.794^{* *}$ & 0.01 \\
\hline weight vs leptin & $0.184^{*}$ & 0.05 \\
\hline \%BF vs leptin & $0.276^{* *}$ & 0.01 \\
\hline BMI vs leptin & $0.383^{\star *}$ & 0.01 \\
\hline HC vs leptin & $0.483^{* *}$ & 0.01 \\
\hline WHR vs leptin & $-0.347^{* *}$ & 0.01 \\
\hline
\end{tabular}

Significant at* $p<0.05 ;{ }^{* *} p<0.01$

vs $=$ versus

Table 5: Pearson Correlation coefficient of leptin with biophysical parameters.

$(\mathrm{r}=0.275 \mathrm{p}<0.01), \% \mathrm{BF}(\mathrm{r}=0.570, \mathrm{p}<0.01)$, BMI $(\mathrm{r}=0.383, \mathrm{p}<0.05)$, hip circumference $(\mathrm{r}=0.462, \mathrm{p}<0.01)$ and inversely correlated with WHR $(\mathrm{r}=-0.347, \mathrm{p}<0.01)$.

Mean serum leptin level showed graded increases within the different socioeconomic classes. The WC was significantly higher in the high income group $(\mathrm{p}<0.01)$ whencompared with the low and middle income groups. (table not shown).

\section{Discussions}

Physical activity and a healthy diet play a pivotal role in the prevention of major chronic diseases vis a vis metabolic syndrome/ CVD. The distribution of obese subjects in the present study showed a preponderance of females in all the obese classes. The ratio of female to male obese was $4: 1$. The hip and waist circumferences as well as percentage body fat showed progressive increases with increasing obesity, feeding habits and sedentary lifestyle may have accounted in part for these changes in our obese subjects. The hip circumference of the female obese was significantly higher than their male counterparts. This change could be attributed to gynoid obesity, a condition in which fats are deposited mainly in the periphery around the hip and thighs. On the other hand the waist circumference was higher in the male obese. Available evidence has shown that abdominal or android obesity is commoner in males than females [21]. Previous studies [2224] showed that metabolic complications are increased in males when waist circumference rises above $102 \mathrm{~cm}$ as against $94 \mathrm{~cm}$. The $\% \mathrm{BF}$ of the obese subjects also increased with increasing BMI.

Serum leptin were significantly raised in all obese subjects, similar to this present findings are reports from different populations that demonstrated that serum leptin concentrations are elevated in human obesity in proportion to the degree of adiposity $[25,26]$. This increase in serum leptin was significantly correlated with all the anthropometric indices (\% BF, HC, WC, BMI and WHR) in all obese subjects. These changes are associated with risk of metabolic syndrome and other chronic diseases. There was a gender variation in serum leptin level, with female subjects exhibiting remarkable higher value. Furthermore, when cofounding factors such as gender and BMI were applied, this increase in serum leptin persisted in the subjects. These variations in leptin concentration between male and female subjects could be related to the distribution of adipose tissue in the two genders as well as hormonal differences [25]. Again Leptin was remarkably increased within the obesity classes. This could be related to the fact that leptin acts as lipostat, as the amount of fat stored in adipocytes rises, leptin is released into the blood. The finding that serum leptin concentrations are elevated in obese subjects has led to the assertions that obesity may in part, be due to resistance action of leptin [27]. The amount of body fat is the main determinant of this hormone as it directly affects the metabolism and function of peripheral tissue such as adipocytes. Leptin expression and secretion have been correlated with body fat and adipocyte [28]. It could be speculated that the increase in serum leptin 
associated with increases in anthropometric indices are indications that increased body compositions invariably gives rise to serum leptin in individuals. This is examplified in obese class III where the highest mean value of serum leptin was obtained.

There were gender variations in the plasma triglyceride and serum leptin levels. The obese males tended to possess higher plasma triglyceride while the obese females exhibited higher serum leptin. Various studies from different populations have reported increased plasma TG in males [29,30]. Earlier study [30] has shown that hypertriglyceridemia could impaired transport of leptin across the blood brain barrier in obesity. Thus suggesting that as the serum TG increases, leptin transport may decrease across the blood brain barrier [29].

The Artherogenic indices measured in this study were increased with increasing obesity, thus indicating that even though the obese appear to be apparently healthy, the likelihood of metabolic syndrome chronic diseases/CVD is apparently. The decreased plasma HDLC, increased TG, raised LDLC/ HDLC in the obese subjects are also indicators of metabolic syndrome and relative risks of premature CVD [29]. Previous study by Goldbount et al. [31] showed that for every $1 \mathrm{mg} / \mathrm{dl}$ decrease in plasma HDLC, the risk of developing CVD is increased by $2.5 \%$.

The waist circumference increases as the socioeconomic class rises, with the high income group exhibiting the highest mean value. Previous report suggested that in low-income countries, wealthier, well-educated people are more likely to be overweight than people who have lower incomes or less schooling [32].

It can be infered from this result that wealthier and more educated who have enough money to pick up "morden food" could be more at risk of chronic diseases associated with obesity.

Serum leptin levels in a large group of obese subjects were correlated with increases in anthropometric indices, thus suggesting that obesity could be a cause of raised serum leptin.

\section{Conclusion}

This study has shown that elevated serum leptin was correlated with anthropometric indicesin a large group of obese Nigerians. These increases are possible risks for metabolic syndrome and other chronic diseases.

\section{References}

1. Finucane MM, Stevens GA, Cowan MJ, Danaei G, Lin JK, et al. (2011) National, regional, and global trends in body-mass index since 1980: systematic analysis of health examination surveys and epidemiological studies with 960 countryyears and 9.1 million participants. Lancet 377: 557-567.

2. Popkin BM (2006) Global nutrition dynamics: the world is shifting rapidly toward a diet linked with noncommunicable diseases. Am J Clin Nutr 84: 289-298.

3. Ezzati M, Vander Hoorn S, Lawes CM, Leach R, James WP, et al. (2005) Rethinking the "diseases of affluence" paradigm: global patterns of nutritional risks in relation to economic development. PLoS Med 2: e133.

4. Monteiro CA, Conde WL, Popkin BM (2007) Income-specific trends in obesity in Brazil: 1975-2003. Am J Public Health 97: 1808-1812.

5. [No authors listed] (2000) Obesity: preventing and managing the global epidemic. Report of a WHO consultation. World Health Organ Tech Rep Ser 894: i-xii, 1-253.

6. Ogunjimi IO, Ikorok MM, Olayinka YO (2010) Prevalence of obesity among Nigeria nurses: The Akwa lbom State experience. International NGO Journal 5: 045-049.

7. Puepet FH, Zoakah Al, Chuhwak EK (2002) Prevalence of overweight and obesity among urban Nigeria adults in Jos. Highland Medical Research Journal 1: 117-125.

8. Hubert HB, Feinleib M, McNamara PM, Castelli WP (1983) Obesity as an independent risk factor for cardiovascular disease: a 26-year follow-up of participants in the Framingham Heart Study. Circulation 67: 968-977.

9. Lee IM, Paffenbarger RS Jr (1998) Physical activity and stroke incidence: the Harvard Alumni Health Study. Stroke 29: 2049-2054.

10. Stanley S, Wynne K, McGowan B, Bloom S (2005) Hormonal regulation of food intake. Physiol Rev 85: 1131-1158.

11. Aizawa-Abe M, Ogawa Y, Masuzaki H, Ebihara K, Satoh N, et al. (2000) Pathophysiological role of leptin in obesity-related hypertension. J Clin Invest 105: 1243-1252.

12. Popkin BM (2011) Does global obesity represent a global public health challenge? Am J Clin Nutr 93: 232-233.

13. Banks WA, Coon AB, Robinson SM, Moinuddin A, Shultz JM, et al. (2004) Triglycerides induce leptin resistance at the blood-brain barrier. Diabetes 53 1253-1260.

14. Mendez MA, Monteiro CA, Popkin BM (2005) Overweight exceeds underweigh among women in most developing countries. Am J Clin Nutr 81: 714-721.

15. Richard GB, M S Hickey (2006) Population variation and differences in serum leptin independent of adiposity: a comparison of Ache Amerindian men of Paraguay and lean American male distance runners. Nutrition \& Metabolism 3: 34 .

16. Lindsay McLaren (2007) Socioeconomic Status and Obesity. Oxford Journals. Medicine \& Health Epidemiologic Reviews 29: 29-48.

17. Ebesunun MO, Agbedana EO, Taylor GO, Oladapo OO (2008) Plasma lipoprotein (a), homocysteine, and other cardiovascular disease (CVD) risk factors in Nigerians with CVD. Appl Physiol Nutr Metab 33: 282-289.

18. Allain CC, Poon LS, Chan CS, Richmond W, Fu PC (1974) Enzymatic determination of total serum cholesterol. Clin Chem 20: 470-475.

19. McGowan MW, Artiss JD, Strandbergh DR, Zak B (1983) A peroxidase-coupled method for the colorimetric determination of serum triglycerides. Clin Chem 29: 538-542.

20. Friedewald WT, Levy RI, Fredrickson DS (1972) Estimation of the concentration of low-density lipoprotein cholesterol in plasma, without use of the preparative ultracentrifuge. Clin Chem 18: 499-502.

21. RAABO E, TERKILDSEN TC (1960) On the enzymatic determination of blood glucose. Scand J Clin Lab Invest 12: 402-407.

22. Okosun IS, Prewitt TE, Cooper RS (1999) Abdominal obesity in the United States: prevalence and attributable risk of hypertension. J Hum Hypertens 13: 425-430.

23. Katzmarzyk PT, Janssen I, Ross R, Church TS, Blair SN (2006) The importance of waist circumference in the definition of metabolic syndrome: prospective analyses of mortality in men. Diabetes Care 29: 404-409.

24. Lemieux I, Pascot A, Couillard C, Lamarche B, Tchernof A, et al. (2000) Hypertriglyceridemic waist: A marker of the atherogenic metabolic triad (hyperinsulinemia; hyperapolipoprotein B; small, dense LDL) in men? Circulation 102: 179-184

25. Caro JF, Sinha MK, Kolaczynski JW, Zhang PL, Considine RV (1996) Leptin the tale of an obesity gene. Diabetes 45: 1455-1462.

26. Chubenko E, Belyaeva O, Bolshakova O, Berkovich O, Bazhenova E (2010) Serum Leptin Concentration in Obese and Hypertensive Patients J Hyper: 28 190.12.465

27. Frederich RC, Hamann A, Anderson S, Löllmann B, Lowell BB, et al. (1995) Leptin levels reflect body lipid content in mice: evidence for diet-induced resistance to leptin action. Nat Med 1: 1311-1314.

28. Sone M, Osamura RY (2001) Leptin and the pituitary. Pituitary 4: 15-23.

29. Montague CT, Farooqi IS, Whitehead JP, Soos MA, Rau H, et al. (1997) Congenital leptin deficiency is associated with severe early-onset obesity in humans. Nature 387: 903-908.

30. Van Heek M, Compton DS, France CF, Tedesco RP, Fawzi AB, et al. (1997) Diet-induced obese mice develop peripheral, but not central, resistance to leptin. J Clin Invest 99: 385-390. 
Citation: Ebesunun MO, Okeke DC (2014) Serum Leptin Correlated with Anthropometric Indices in obese Subjects. J Metabolic Synd 3: 157. doi:10.4172/2167-0943.1000157

31. Goldbourt U, Yaari S, Medalie JH (1997) Isolated low HDL cholesterol as a risk factor for coronary heart disease mortality. A 21-year follow-up of 8000 men. Arterioscler Thromb Vasc Biol 17: 107-113.
32. Monteiro CA, Moura EC, Conde WL, Popkin BM (2004) Socioeconomic status and obesity in adult populations of developing countries: a review. Bull World Health Organ 82: 940-946. 